\title{
Perbandingan Return dan Risiko Saham Subsektor Perbankan dengan Subsektor Property Real Estate yang Terdaftar di BEI
}

\author{
Comparison of stock return and risk banking subsector and property, real estate \\ subsector listed on IDX
}

\section{Ladysa Awala}

Program Studi D3 Keuangan dan Perbankan, Politeknik Negeri Bandung

E-mail: ladysaawala25@gmail.com

\section{Tjetjep Djuwarsa}

Jurusan Akuntansi, Politeknik Negeri Bandung

E-mail: tjetjepdjuwarsa@yahoo.com

\section{Dimas Sumitra Danisworo}

Jurusan Akuntansi, Politeknik Negeri Bandung

E-mail:dimas.sumitra@polban.ac.id

\begin{abstract}
The Indonesia Stock Exchange (IDX) noted the rise investors during 2019. In addition, some of the sector on the market capital shows the rapid development. It can be seen from a stock transactions. However, the developments is not indicate the return and risk of every sector. This research aims to determine differences in return and risk of stock between banking subsector and property, real estate subsector on the period 2019. The data used are secondary data obtained from Indonesia Stock Exchange and Id Investing. The research sample used was of 16 (sixteen) companies stock in the banking subsector and 14 (fourteen) companies stock in the property, real estate. This study used the Mann Whitney Test using SPSS version 24 software as analysis tool. The result of this research shows that there is no significant difference return and risk between banking subsector and property, real estate subsector.
\end{abstract}

Keywords: stock return, stock risk, banking, property, real estate

\section{Pendahuluan}

\subsection{Latar Belakang}

Bursa Efek Indonesia mencatat terjadinya kenaikan jumlah investor sepanjang tahun 2019. Jumlah investor yang tercatat dalam pasar modal menunjukkan peningkatan yang signifikan sebanyak 53\% dari 1,6 juta pada tahun 2018 menjadi 2,4 juta di tahun 2019 berdasarkan single investor identification (SID). Aktivitas perdagangan di pasar modal meningkat, terbukti dari tumbuhnya frekuensi perdagangan yang meningkat sebesar 21\% (Puspitasari, 2019). Di samping itu beberapa kelompok saham di bursa efek juga menunjukkan perkembangan yang pesat di antaranya subsektor perbankan dan property, real estate dapat dilihat dari kenaikan frekuensi perdagangan dan kapitalisasi pasar (tahun 2018 hingga 2019). Perkembangan tersebut tampak pada tabel berikut: 


\section{Ladysa Awala, Tjetjep Djuwarsa, Dimas Sumitra Danisworo}

Tabel 1 Pertumbuhan Transaksi Saham

\begin{tabular}{|l|c|c|c|c|}
\hline \multirow{2}{*}{\multicolumn{1}{|c|}{ Indikator }} & \multicolumn{2}{|c|}{ Perbankan } & \multicolumn{2}{c|}{ Property, Real Estate } \\
\cline { 2 - 5 } & $\mathbf{2 0 1 8}$ & $\mathbf{2 0 1 9}$ & $\mathbf{2 0 1 8}$ & $\mathbf{2 0 1 9}$ \\
\hline Frekuensi Perdagangan (kali) & 10.151 & 11.466 & 7.427 & 10.154 \\
\hline Kapitalisasi Pasar (triliun) & 2.002 .477 & 2.303 .146 & 289.335 & 389.907 \\
\hline
\end{tabular}

Sumber: www.idx.co.id

Berdasarkan tabel 1, aktivitas perdagangan di bursa efek menunjukkan perubahan yang baik jika ditinjau pada kedua aspek transaksi saham subsektor perbankan yang lebih besar dari subsektor property, real estate. Apabila ditinjau dari aspek laba Otoritas Jasa Keuangan mencatat subsektor perbankan mencetak laba bersih sebesar Rp 117,59 triliun. Berdasarkan data Statistik Perbankan Indonesia pencapaian laba tersebut dikontribusi oleh 110 bank umum. Beberapa contoh di antaranya PT Bank Mandiri (Persero) Tbk mengalami kenaikan laba sebesar 23,43\% dan PT Bank Mega Tbk sebesar 43,9\%. Pertumbuhan laba bersih tersebut ditopang oleh penyaluran kredit perbankan yang meningkat 7,89\%. Penyaluran kredit yang meningkat merupakan dampak positif dari penurunan tingkat suku bunga acuan oleh pemerintah pada tahun 2019. Pada subsektor property, real estate penurunan tingkat suku bunga acuan akan berakibat pada turunnya tingkat suku bunga kredit pemilikan rumah, hal ini semestinya mendorong pertumbuhan penjualan properti. Subsektor property, real estate di tahun 2019 memiliki kinerja yang kurang konsisten. Pada kenyataannya laba kelompok saham ini masih sangat berfluktuatif, bahkan emiten PT PP Properti Tbk membukukan laba bersih yang menurun sebesar 28\%. Namun, subsektor property, real estate merupakan salah satu sektor yang memiliki valuasi murah, sehingga hal tersebut membuat harga sahamnya mengalami kenaikan (Herlambang, 2019). Perkembangan subsektor perbankan dan property, real estate di pasar modal akan mendorong permintaan saham dan menarik perhatian para investor untuk menanamkan dana miliknya pada kelompok saham tersebut. Ketertarikan tersebut tentunya didasarkan pada return atau kentungan yang akan diperoleh para investor. Akan tetapi, pertumbuhan laba dan besarnya frekuensi perdagangan serta kapitalisasi pasar subsektor perbankan belum tentu mencerminkan bahwa nilai return dan risiko kelompok saham perbankan lebih baik daripada kelompok saham property, real estate.

Dalam berinvestasi di pasar modal perlu melakukan perhitungan atas keuntungan yang akan diharapkan dan memperhitungkan risiko dari instrumen tersebut. Salah satu return pemilik saham dalam berinvestasi di bursa efek adalah dividen. Dividen adalah laba yang diperoleh suatu emiten dan dibayarkan sebagian kepada para investor. Dividen yang dibayarkan sangat bergantung pada kemampuan sebuah perusahaan dalam menghasilkan laba. Bagi investor, dividen adalah bentuk imbal hasil investasi yang ditanamkan. Perusahaan yang memberikan dividen tinggi merupakan hal yang menarik bagi penanam modal untuk menanamkan modalnya sehingga reputasi perusahaan akan meningkat. Selain dividen, return yang akan diperoleh investor dalam berinvestasi saham yaitu capital gain yang dapat dilihat dari fluktuasi pergerakan harga saham. Fluktuasi harga saham pada setiap investasi bisa menjadi prospek bagi pemilik modal untuk memutuskan pilihan investasi saham pada besaran return yang dikehendaki dan risiko yang akan diterima oleh penanam modal tersebut (Tandelilin, 2015). Harapan dari pemegang saham mengenai investasinya adalah untuk menerima tingkat imbal hasil (return) yang besar dengan tingkat risiko tertentu. Namun, karena investor menghadapi peluang investasi yang akan memiliki risiko sehingga pilihan investasi tidak bisa hanya menggantungkan pada tingkat return yang diinginkan. Hubungan return dan risiko yang positif akan berlaku pada pasar yang efisien dan sempurna. Risiko akan semakin besar apabila seorang investor mengharapkan tingkat return yang tinggi (Hanafi, 2012:214).

Beberapa penelitian yang dilakukan untuk melihat perbandingan return dan risiko saham telah menunjukkan perbedaan hasil penelitian sehingga dapat dikatakan terjadi ketimpangan pada 
penelitian-penelitian terdahulu. Beberapa penelitian tersebut di antaranya dilakukan oleh Kasanah dan Worokinasih (2018), Jamil, Putra dan Mansur (2019), Binanga, Dayaan, dan Mardhiah (2017), Tendean, Saerang dan Tulung (2019), dan Kusbiyantoro (2019). Kasanah dan Worokinasih (2018) melakukan penelitian terhadap Saham Syariah dengan Saham Konvensional dan penelitian tersebut memiliki kesimpulan bahwa return maupun risiko saham tidak memiliki perbedaan yang signifikan. Kemudian Jamil, Putra dan Mansur (2019) melakukan penelitian terhadap sektor perkebunan pada BEI dan Bursa Efek Malaysia, penelitian ini memperoleh hasil bahwa return saham menunjukkan adanya perbedaan yang signifikan. Penelitian selanjutnya dilakukan oleh Binanga, Dayaan, dan Mardhiah (2017) terhadap Indeks Syariah dengan Non Indeks Syariah, penelitian tersebut mengungkapkan jika tidak ada perbedaan yang signifikan antara risiko maupun return. Sejalan dengan hasil penelitian Tendean, Saerang dan Tulung (2019) terhadap Saham JII dan Indeks LQ45. Kesimpulan penelitian ini menjelaskan bahwa risiko saham tidak memiliki perbedaan yang signifikan. Kusbiyantoro (2019) juga melakukan penelitian serupa terhadap variabel risiko investasi sektor pertambangan dan sektor industri barang dan konsumsi, penelitian tersebut menjelaskan bahwa ada perbedaan yang signifikan risiko investasi.

Atas penjelasan, fenomena, dan perbedaan penelitian sebelumnya, maka penulis mengkaji penelitian dengan judul "Perbandingan Return dan Risiko Saham Subsektor Perbankan dengan Subsektor Property Real Estate yang Terdaftar di BEI".

\section{Tinjauan Pustaka}

\subsection{Pasar Modal}

Pasar modal yaitu sarana bertemunya permintaan maupun penawaran surat berharga. Tempat berbagai pelaku pasar seperti masyarakat perseorangan atau suatu organisasi yang memiliki dana lebih (surplus fund) menjalankan aktivitas penanaman modal dalam bentuk efek-efek yang ditawarkan ataupun diperjualbelikan oleh perusahaan. Sedangkan perusahaan yang memerlukan suatu modal menawarkan efek-efek dengan cara terlebih dulu mendaftarkan perusahaan pada pihak yang berwenang di pasar modal untuk menjadi perusahaan terbuka atau emiten (Sunariyah, 2011:5).

\subsection{Investasi}

Sunariyah (2011:1) menyatakan di dalam bukunya yang berjudul "Pengantar Pengetahuan Pasar Modal" bahwa investasi yaitu penanaman sejumlah modal untuk satu atau lebih asset yang dimiliki dan biasanya berjangka waktu panjang dengan keinginan memperoleh keuntungan di waktu-waktu yang akan datang. Fahmi (2012:3) menjelaskan bahwa tujuan dalam melakukan investasi yakni sebagai berikut:

1. Terbentuknya investasi yang berkepanjangan (continuity).

2. Terbentuknya keuntungan yang diharapkan (profit actual) atau keuntungan yang maksimal.

3. Terbentuknya kenyamanan bagi para pemegang saham.

4. Serta memberikan peranan bagi pembangunan negara.

\subsection{Saham}

Fahmi (2012:81) mengungkapkan definisi saham merupakan bukti pelibatan kepemilikan sejumlah dana atau modal berupa lembar kertas yang berisi nama perusahaan, nilai, serta diikuti dengan kewajiban dan hak yang dinyatakan kepada setiap pemegangnya pada suatu perusahaan. Saham yakni salah satu instrumen pasar modal yang paling diketahui oleh publik. Penerbitan saham menjadi salah satu opsi perusahaan yang dipakai untuk menghimpun dana dari publik. Bentuk saham yaitu lembar kertas yang menjelaskan bahwa yang mempunyai kertas tersebut juga pemilik perusahaan penerbit saham bersangkutan (Halim, 2018:7). 


\subsection{Return}

Menurut Halim (2018:51) dalam kaitannya dengan manajemen investasi, imbal hasil (return) yaitu imbalan yang didapatkan atas kegiatan investasi. Pada pasar modal, besar pengembalian yang diterima oleh seorang penanam modal dari saham yang diperjualbelikan di pasar modal (saham emiten go public) umumnya dikenal dengan return. Saham tidak senantiasa menjanjikan suatu return yang pasti bagi pemegang saham. Akan tetapi elemen return saham yang mungkin akan diterima oleh pemodal dalam meraih keuntungan adalah dividen dan capital gain. Rumus perhitungan actual return dapat dihitung menggunakan rumus sebagai berikut (Halim, 2018:32):

$$
\mathrm{Ri}=\frac{\mathrm{Dt}+\mathrm{Pt}-\mathrm{Pt}-1}{\mathrm{Pt}-1}
$$

Sedangkan return rata-rata dapat dihitung menggunakan rumus sebagai berikut (Halim, 2018:53):

$$
\mathrm{E}(\mathrm{Ri})=\frac{\sum_{\mathrm{i}}^{\mathrm{n}}=1(\mathrm{Ri})}{\mathrm{N}}
$$

Keterangan:

$\mathrm{E}(\mathrm{R} i)=$ Rata-rata return.

$\mathrm{R} i=$ Nilai ke-i.

Dt $=$ Dividen yang diterima periode $\mathrm{t}$.

$\mathrm{Pt} \quad=$ Harga untuk periode $\mathrm{t}$.

Pt-1 = Harga untuk periode sebelumnya.

$\mathrm{N}=$ Imbal hasil yang terjadi pada periode pengamatan.

\subsection{Risiko}

Menurut Halim (2018:57) mendefinisikan bahwa risiko adalah deviasi dari keuntungan yang diharapkan investor (expected return) dengan nilai keuntungan yang telah terjadi (actual return). Jika penyimpangan tersebut nilainya besar maka semakin besar pula tingkat risikonya. Penyimpangan atau risiko dapat dihitung menggunakan rumus sebagai berikut (Halim, 2018:60):

$$
\sigma i=\sqrt{\frac{\sum_{\mathrm{i}}^{\mathrm{n}}=1[\mathrm{Ri}-\mathrm{E}(\mathrm{Ri})]^{2}}{\mathrm{n}}}
$$

Keterangan:

$$
\begin{array}{ll}
\sigma & =\text { Standard deviation. } \\
\mathrm{Ri} & =\text { Nilai ke-i. } \\
\mathrm{E}(\mathrm{Ri}) & =\text { Nilai ekspektasi. } \\
\mathrm{N} & =\text { Imbal hasil yang terjadi pada periode pengamatan. }
\end{array}
$$

\subsection{Hubungan Return dan Risiko}

Menurut Jogiyanto (2014:257) return dengan risiko memiliki kaitan yang searah atau positif, makin tinggi suatu return yang dikompensasikan, maka akan semakin besar pula risiko yang ditanggung. Apabila makin kecil return yang diharapkan maka semakin kecil risiko yang harus ditanggung. Hubungan yang searah ini hanya terjadi untuk return ekspektasi. Untuk actual return, hubungan positif ini tidak dapat terjadi. Actual return yang nilainya besar tidak selalu memiliki risiko yang besar pula bagi pasar rasional. Kondisi sebaliknya pun bisa terjadi yakni actual return dengan nilai yang besar memiliki nilai risiko yang kecil.

\subsection{Kerangka Pemikiran}

Bursa Efek Indonesia (BEI) merupakan media untuk melakukan kegiatan penawaran jual dan beli berbagai surat berharga salah satu contohnya adalah saham. Dalam melakukan investasi saham 
seorang investor dapat memilih berbagai kelompok saham. Investor akan menentukan berinvestasi pada saham yang diharapkan memberikan besar keuntungan yang seimbang terhadap risiko yang diperoleh. Hal utama dalam berinvestasi saham adalah mempertimbangkan tingkat keuntungan dan kerugian yang akan dihadapi (Suresh, 2018). Untuk mengetahui tingkat keuntungan tersebut dapat dilakukan dengan membandingkan return dan risiko beberapa kelompok saham. Berdasarkan pemaparan di atas, maka kerangka pemikiran yang menggambarkan perbedaan risiko dan return antara dua kelompok seperti berikut:

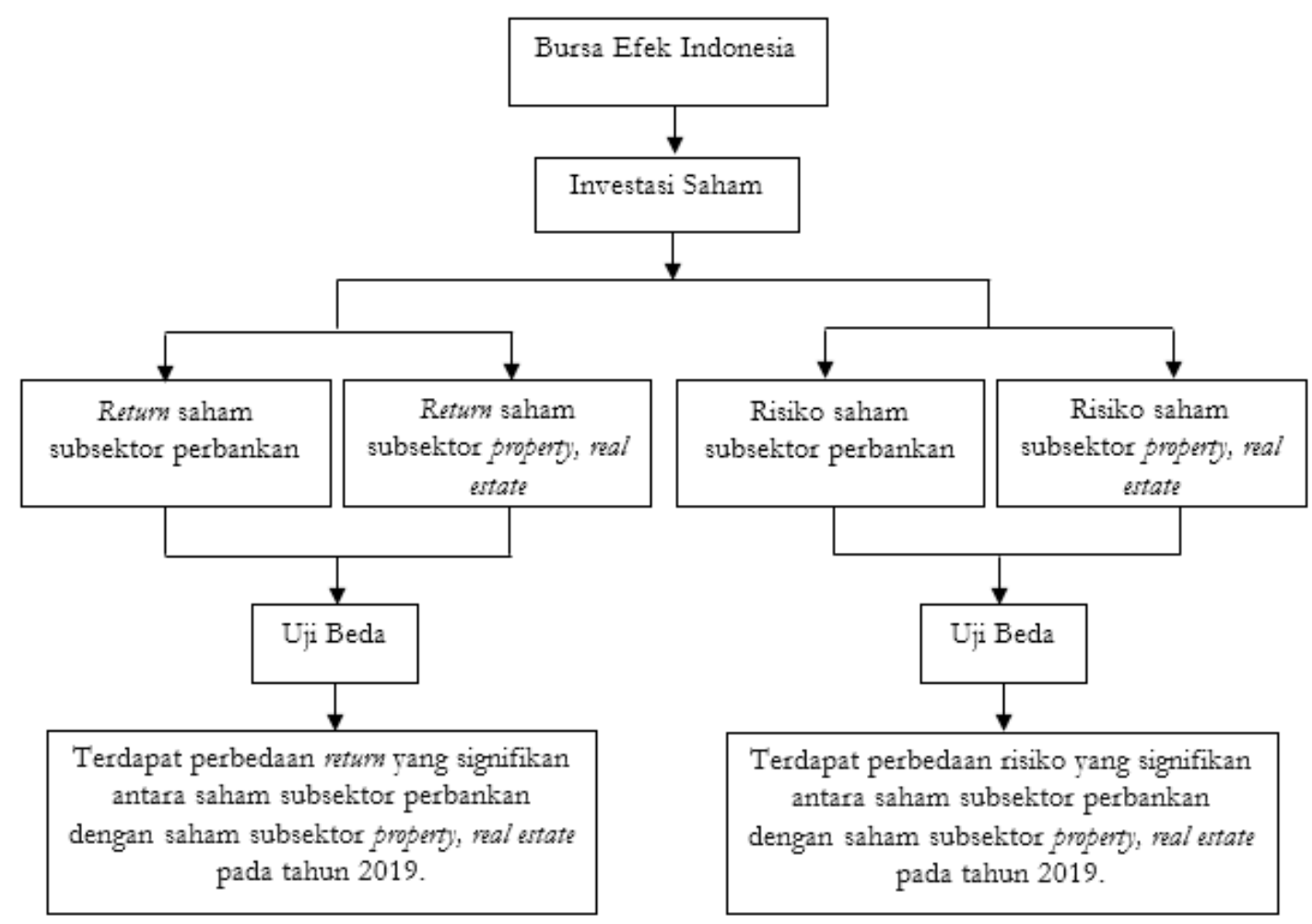

Gambar 1 Kerangka Pikir

\section{Metode Penelitian}

Metode penelitian kuantitatif yaitu digunakan untuk meneliti population atau sample yang digunakan berdasarkan positivism philosophy. Metode tersebut dipakai karena data yang menjadi sasaran yaitu data berupa angka-angka. Sedangkan jenis penelitian yang dipakai yakni penelitian deskriptif. Sedangkan data bersumber dari data tidak langsung dengan kata lain data sekunder. Data sekunder dalam penelitian ini yaitu data time series dan cross section dari laporan statistik pergerakan harga saham yang diperoleh melalui situs resmi BEI.

\subsection{Sampel Penelitian}

Teknik menentukan sampel yang dipakai pada penelitian ini yakni purposive sampling. Berdasarkan tujuan penelitian maka sampel harus memenuhi kriteria berikut:

1. Termasuk kelompok saham dalam subsektor perbankan dan subsektor property, real estate yang listed pada tahun 2019.

2. Saham-saham perusahaan tersebut diperdagangkan dimulai dari bulan Desember 2018.

3. Saham yang memberikan dividen pada tahun 2019.

Dari ketiga pertimbangan di atas sehingga sampel penelitian terdapat 30 perusahaan dengan subsektor perbankan sebanyak 16 saham dan subsektor property, real estate sebanyak 14 saham. 


\subsection{Teknik Analisis Data}

Cara yang dipakai yaitu uji beda yang akan digunakan untuk mengolah data sebagai berikut:

1. Menghitung nilai return dari tiap-tiap saham menggunakan rumus return individual.

2. Menghitung nilai expected return setiap saham dan risiko saham menggunakan rumus standar deviasi.

3. Menghitung risiko saham menggunakan rumus standar deviasi.

4. Statistik Deskriptif

5. Uji Normalitas

Dasar pengambilan keputusan uji normalitas ini adalah sebagai berikut:

Jika nilai signifikansi $>0,05$ maka data berdistribusi normal.

Jika nilai signifikansi $<0,05$ maka data tidak berdistribusi normal.

6. Uji Mann Whitney

Pengambilan keputusan dapat dilihat dari nilai signifikansi dengan kriteria sebagai berikut: Apabila besarnya nilai signifikansi $<0,05$ maka terdapat perbedaan yang signifikan.

Apabila besarnya nilai signifikansi $>0,05$ maka tidak terdapat perbedaan yang signifikan.

7. Uji Hipotesis

a. Tentukan hipotesis $(\mathrm{H} 0)$ dan hipotesis alternatif $(\mathrm{H} 1)$

Uji hipotesis yang pertama dilakukan pada variabel return saham dengan hipotesis:

H0 = Tidak terdapat perbedaan return yang signifkan antara saham subsektor perbankan dengan saham subsektor property, real estate pada tahun 2019.

$\mathrm{H} 1$ = Terdapat perbedaan return yang signifkan antara saham subsektor perbankan dengan saham subsektor property, real estate pada tahun 2019.

Sedangkan uji hipotesis yang kedua dilakukan pada variabel risiko saham dengan hipotesis:

H0 = Tidak terdapat perbedaan risiko yang signifikan antara saham subsektor perbankan dengan saham subsektor property, real estate pada tahun 2019.

$\mathrm{H} 1$ = Terdapat perbedaan risiko yang signifikan antara saham subsektor perbankan dengan saham subsektor property, real estate pada tahun 2019.

b. Pengambilan keputusan daerah dan penolakan hipotesis:

Apabila besarnya signifikansi $>0,05$ maka H0 diterima

Apabila besarnya signifikansi $<0,05 \mathrm{H} 0$ ditolak.

\section{Hasil \& Pembahasan}

\subsection{Statstik Deskriptif}

Tabel 2 Statstik Deskriptif Return dan Risiko Saham

\begin{tabular}{|c|l|c|c|c|c|}
\hline Variabel & \multicolumn{1}{|c|}{ Subsektor } & N & Minimum & Maksimum & Mean \\
\hline \multirow{2}{*}{ Return Saham } & Perbankan & 16 & 0,06 & 57,94 & 9,31 \\
\cline { 2 - 6 } & Property, Real Estate & 14 & 0,05 & 49,02 & 6,96 \\
\hline \multirow{2}{*}{ Risiko Saham } & Perbankan & 16 & 0,34 & 129,55 & 26,98 \\
\cline { 2 - 6 } & Property, Real Estate & 14 & 0,28 & 162,54 & 23,05 \\
\hline
\end{tabular}

Sumber: data diolah 
Tabel 2 menunjukkan bahwa jumlah sampel return saham subsektor perbankan adalah sebanyak 16 perusahaan dengan return terendah sebesar 0,06, return tertinggi sebesar 57,94, dan nilai rata-rata return saham sebesar 9,31. Sedangkan jumlah sampel return saham subsektor property, real estate adalah sebanyak 14 perusahaan dengan return terendah sebesar 0,05, return tertinggi sebesar 49,02, dan nilai rata-rata return saham sebesar 6,96.

Risiko saham subsektor perbankan memiliki jumlah sampel 16 perusahaan dengan risiko terendah sebesar 0,34, risiko tertinggi sebesar 129,55, dan rata-rata risiko saham sebesar 26,98. Sedangkan risiko saham subsektor property, real estate memiliki jumlah sampel 14 perusahaan dengan risiko terendah sebesar 0,28 , risiko tertinggi sebesar 162,54 , dan rata-rata risiko saham sebesar 23,05 .

\subsection{Uji Normalitas}

1. Uji Normalitas Variabel Return Saham

Tabel 3 Uji Normalitas Variabel Return Saham

\begin{tabular}{|c|r|r|r|r|r|c|}
\hline \multicolumn{1}{|c|}{ Tests of Normality } \\
\hline & \multicolumn{3}{|c|}{ Kolmogorov-Smirnov' } & \multicolumn{3}{|c|}{ Shapiro-Wilk } \\
\cline { 2 - 7 } & Statistic & \multicolumn{1}{|c|}{ Df } & \multicolumn{1}{|c|}{ Sig } & Statistic & Df & Sig. \\
\hline Return Saham &, 284 & 30 &, 000 &, 616 & 30 &, 000 \\
\hline
\end{tabular}

Sumber: data diolah menggunakan SPSS 24

Pada hasil Uji Normalitas Shapiro-Wilk tampak dari tabel 3 perolehan nilai signifikansi untuk return saham adalah 0,000. Karena hasil signifikansi return saham tersebut lebih rendah dari $\alpha=0,05$, sehingga memiliki makna bahwa data return saham kedua subsektor tersebut berdistribusi tidak normal. Hasil uji normalitas juga tercermin pada gambar 2 di bawah ini:

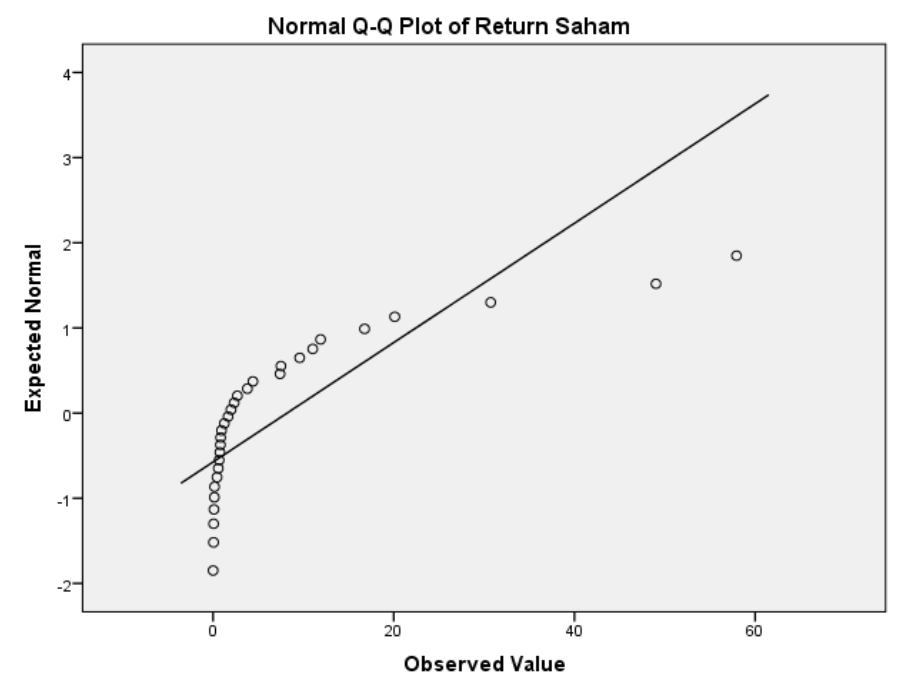

Gambar 2 Normalitas Q-Q Plot Return Saham

Sumber: data diolah menggunakan SPSS 24

Gambar 2 menunjukkan data return saham tidak menyebar di sekitar garis lurus dan terdapat data yang letaknya jauh dari garis lurus. Sehingga dapat memiliki makna bahwa data return saham berdistribusi tidak normal.

2 Uji Normalitas Variabel Risiko Saham 
Tabel 4 Uji Normalitas Variabel Risiko Saham

\begin{tabular}{|c|r|r|r|r|r|c|}
\hline \multicolumn{8}{|c|}{ Tests of Normality } \\
\hline & \multicolumn{3}{|c|}{ Kolmogorov-Smimov's } & \multicolumn{3}{|c|}{ Shapiro-Wilk } \\
\cline { 2 - 7 } & Statistic & df & \multicolumn{1}{|c|}{ Sig- } & Statistic & Df & Sig. \\
\hline Risiko Saham &, 270 & 30 &, 000 &, 656 & 30 &, 000 \\
\hline
\end{tabular}

Sumber: data diolah menggunakan SPSS 24

Pada hasil Uji Normalitas Shapiro-Wilk tampak dari tabel 4 perolehan nilai signifikansi untuk risiko saham adalah 0,000. Karena hasil signifikansi return saham tersebut lebih rendah dari $\alpha=0,05$, sehingga memiliki makna bahwa data risiko saham kedua subsektor tersebut berdistribusi tidak normal. Hasil uji normalitas juga tercermin pada gambat 3 di bawah ini:

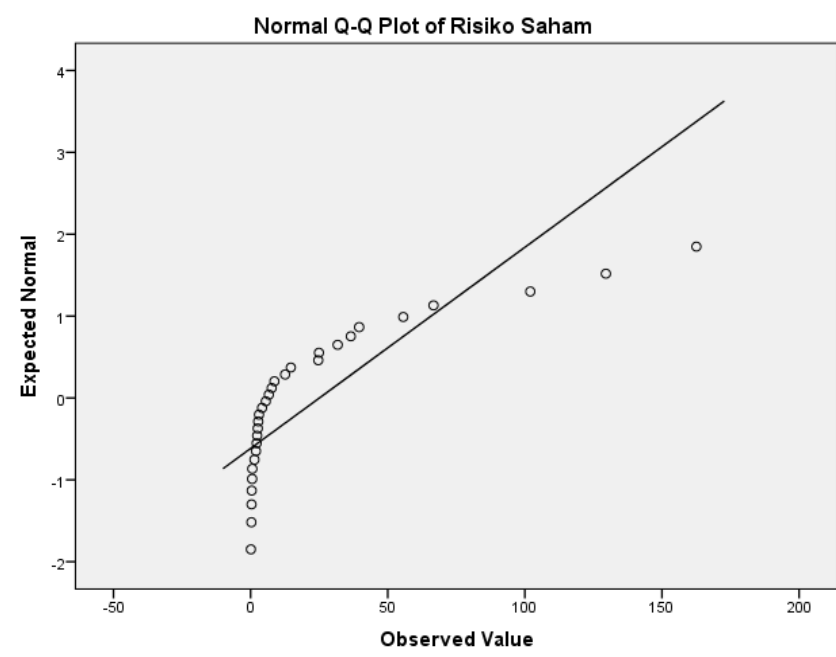

Gambat 3 Normalitas Q-Q Plot Risiko Saham

Sumber: data diolah menggunakan SPSS 24

Gambar 3 menunjukkan data risiko saham tidak menyebar di sekitar garis lurus dan terdapat data yang letaknya jauh dari garis lurus. Sehingga dapat memiliki makna bahwa data risiko saham berdistribusi tidak normal.

\subsection{Uji Mann Whitney}

1. Uji Mann Whitney Variabel Return Saham

Tabel 5 Uji Mann Whitney Variabel Return Saham

\begin{tabular}{|l|c|}
\hline \multicolumn{2}{|c|}{ Test Statistics ${ }^{2}$} \\
\hline & Return \\
\hline Mann-Whitney U & 78,000 \\
\hline Wilcoxon W & 183,000 \\
\hline Z & $-1,413$ \\
\hline Asymp. Sig. (2-tailed) &, 158 \\
\hline Exact Sig. [2*(1-tailed Sig.)] &, $166 \mathrm{~b}$ \\
\hline
\end{tabular}


Berdasarkan tabel 5 tampak asymp. sig (2-tailed) memperoleh nilai 0,158. Karena hasil nilai signifikansi data return saham lebih tinggi dari ketentuan taraf signifikansi yaitu $0,158>0,05$, sehingga memiliki makna bahwa H0 diterima. Kesimpulan tersebut memiliki arti tidak terdapat perbedaan return yang signifikan antara saham subsektor perbankan dengan saham subsektor property, real estate pada tahun 2019.

2. Uji Mann Whitney Risiko Saham

Tabel 6 Uji Mann Whitney Variabel Risiko Saham

\begin{tabular}{|l|c|}
\hline \multicolumn{2}{|c|}{ Test Statistics ${ }^{2}$} \\
\hline & Risiko \\
\hline Mann-Whitney U & 79,000 \\
\hline Wilcoxon W & 184,000 \\
\hline Z & $-1,372$ \\
\hline Asymp. Sig. (2-tailed) &, 170 \\
\hline Exact Sig. [2*(1-tailed Sig.)] &, $179 \mathrm{~b}$ \\
\hline
\end{tabular}

Sumber: data diolah menggunakan SPSS 24

Berdasarkan tabel 6 tampak asymp. sig (2-tailed) memperoleh nilai 0,170. Karena hasil nilai signifikansi data risiko saham lebih tinggi dari kententuan taraf signifikansi yaitu $0,170>0,05$, sehingga memiliki makna bahwa H0 diterima. Kesimpulan tersebut memiliki arti tidak terdapat perbedaan risiko yang signifikan antara saham subsektor perbankan dengan saham subsektor property, real estate pada tahun 2019.

\subsection{Return dan Risiko Saham Subsektor Perbankan}

Tabel 7 Expected Return dan Risiko Subsektor Perbankan Tahun 2019

\begin{tabular}{|c|l|c|c|c|}
\hline No & \multicolumn{1}{|c|}{ Nama } & $\begin{array}{c}\text { Return } \\
\text { Rata-rata }\end{array}$ & Risiko & Rasio \\
\hline 1 & Bank Rakyat Indonesia Agroniaga Tbk & 0,14 & 0,56 & 4,13 \\
\hline 2 & Bank Central Asia Tbk & 57,94 & 129,55 & 2,24 \\
\hline 3 & Bank Negara Indonesia (Persero) Tbk & 16,77 & 55,66 & 3,32 \\
\hline 4 & Bank Rakyat Indonesia (Persero) Tbk & 11,03 & 36,54 & 3,31 \\
\hline 5 & Bank Tabungan Negara (Persero) Tbk & 4,41 & 14,66 & 3,33 \\
\hline 6 & Bank Danamon Indonesia Tbk & 11,90 & 39,58 & 3,33 \\
\hline 7 & BPD Jawa Barat dan Banten Tbk & 7,41 & 24,66 & 3,33 \\
\hline 8 & BPD Jawa Timur Tbk & 3,80 & 12,58 & 3,31 \\
\hline 9 & Bank Maspion Indonesia Tbk & 0,67 & 2,21 & 3,31 \\
\hline 10 & Bank Mandiri (Persero) Tbk & 20,11 & 66,68 & 3,32 \\
\hline 11 & Bank Bumi Arta Tbk & 0,93 & 3,04 & 3,27 \\
\hline 12 & Bank CIMB Niaga Tbk & 2,34 & 7,69 & 3,29 \\
\hline 13 & Bank Maybank Indonesia Tbk & 0,60 & 1,98 & 3,27 \\
\hline 14 & Bank BRIsyariah Tbk & 0,06 & 0,34 & 5,95 \\
\hline 15 & Bank Mega Tbk & 9,59 & 31,73 & 3,31 \\
\hline
\end{tabular}




\begin{tabular}{|c|c|c|c|c|}
\hline No & Nama & $\begin{array}{c}\text { Return } \\
\text { Rata-rata }\end{array}$ & Risiko & Rasio \\
\hline 16 & Bank Woori Saudara 1906 Tbk & 1,25 & 4,15 & 3,32 \\
\hline \multicolumn{2}{|c|}{ Rata-rata } & $\mathbf{9 , 3 1}$ & $\mathbf{2 6 , 9 8}$ & \\
\hline
\end{tabular}

Sumber: data diolah

Berdasarkan tabel 7 terdapat perusahaan yang memiliki expected return tertinggi maupun terendah. Pada tahun 2019 perusahaan pada subsektor perbankan yang memiliki expected return dan risiko tertinggi yaitu Bank Central Asia Tbk sebesar 57,94, dan risiko sebesar 129,55. Artinya return akan terjadi antara 57,94 -129,55 = -71,61 dan 57,94 +129,55 = 187,49. Sedangkan berdasarkan perhitungan diperoleh return bulanan Bank Central Asia Tbk berada antara -0,02 sampai 355,06 sehingga hasilnya jauh berbeda. Selain memberikan expected return dan risiko yang paling tinggi, jika dilihat dari proporsinya perusahaan ini menunjukkan proporsi yang paling kecil di antara perusahaan lainnya yaitu sebesar 2,24. Maka dapat dikatakan Bank Central Asia Tbk memiliki expected return dan risiko yang proporsional.

Sedangkan expected return terendah diperoleh Bank BRI Syariah Tbk sebesar 0,06 dengan nilai risiko terendah pula sebesar 0,34 . Artinya return akan terjadi antara $0,06-0,34=-0,28$ dan $0,06+0,34=0,4$. Namun, berdasarkan perhitungan diperoleh return bulanan Bank BRI Syariah Tbk berada antara -0,18 sampai dengan 1,15, sehingga hasilnya jauh berbeda. Jika dilihat dari proporsinya perusahaan ini memberikan proporsi yang paling tinggi di antara perusahaan lainnya yaitu sebesar 5,95. Maka dapat dikatakan Bank BRI Syariah Tbk memiliki expected return dan risiko yang tidak proporsional.

Selain itu, terdapat beberapa perusahaan yang memperoleh expected return lebih besar dari ratarata yaitu Bank Central Asia Tbk, Bank Negara Indonesia (Persero) Tbk, Bank Rakyat Indonesia (Persero) Tbk, Bank Danamon Indonesia Tbk, Bank Mandiri (Persero) Tbk, Bank Mega Tbk. Selanjutnya dapat dilihat pula perusahaan yang memiliki nilai risiko yang lebih rendah dari rataratanya yaitu Bank Rakyat Indonesia Agroniaga Tbk, Bank Tabungan Negara (Persero) Tbk, BPD Jawa Barat dan Banten Tbk, BPD Jawa Timur Tbk, Bank Maspion Indonesia Tbk, Bank Bumi Arta Tbk, Bank CIMB Niaga Tbk, Bank Maybank Indonesia Tbk, Bank BRIsyariah Tbk, dan Bank Woori Saudara 1906 Tbk.

\subsection{Return dan Risiko Saham Subsektor Property, Real Estate}

Tabel 8 Expected Return dan Risiko Subsektor Property, Real Estate Tahun 2019

\begin{tabular}{|c|l|c|c|c|}
\hline No & \multicolumn{1}{|c|}{ Nama } & $\begin{array}{c}\text { Return } \\
\text { Rata-rata }\end{array}$ & Risiko & Rasio \\
\hline 1 & Bekasi Fajar Industrial Estate Tbk & 0,75 & 2,37 & 3,17 \\
\hline 2 & Ciputra Development Tbk & 0,84 & 2,79 & 3,31 \\
\hline 3 & Intiland Development Tbk & 0,16 & 0,62 & 3,89 \\
\hline 4 & Puradelta Lestari Tbk & 2,69 & 8,66 & 3,23 \\
\hline 5 & Gowa Makassar Tourism Tbk & 1,67 & 5,52 & 3,30 \\
\hline 6 & Perdana Gapuraprima Tbk & 0,05 & 0,28 & 5,24 \\
\hline 7 & Jaya Real Property Tbk & 1,99 & 6,65 & 3,34 \\
\hline 8 & Metropolitan Kentjana Tbk & 30,73 & 101,98 & 3,32 \\
\hline 9 & Metropolitan Land Tbk & 0,81 & 2,59 & 3,21 \\
\hline 10 & Plaza Indonesia Realty Tbk & 49,02 & 162,54 & 3,32 \\
\hline 11 & PP Properti Tbk & 0,10 & 0,40 & 4,13 \\
\hline
\end{tabular}




\begin{tabular}{|c|l|c|c|c|}
\hline No & \multicolumn{1}{|c|}{ Nama } & $\begin{array}{c}\text { Return } \\
\text { Rata-rata }\end{array}$ & Risiko & Rasio \\
\hline 12 & Pakuwon Jati Tbk & 0,58 & 1,94 & 3,35 \\
\hline 13 & Roda Vivatex Tbk & 7,51 & 24,90 & 3,31 \\
\hline 14 & Summarecon Agung Tbk & 0,44 & 1,41 & 3,17 \\
\hline & Rata-rata & $\mathbf{6 , 9 5}$ & $\mathbf{2 3 . 0 5}$ & \\
\hline
\end{tabular}

Sumber: data diolah

Berdasarkan tabel 8 terdapat perusahaan yang memiliki expected return tertinggi maupun terendah. Pada tahun 2019 perusahaan pada subsektor property, real estate yang memiliki expected return tertinggi yaitu Plaza Indonesia Realty Tbk sebesar 49,02 dengan nilai risiko yang paling tinggi pula sebesar 162,54. Artinya return akan terjadi antara 49,02 - 162,54 = -113,52 dan 49,02 + 162,54= 211,56. Sedangkan berdasarkan perhitungan diperoleh return bulanan Plaza Indonesia Realty Tbk berada antara -0,22 sampai dengan 588,11, sehingga hasilnya jauh berbeda. Selain memberikan expected return dan risiko yang paling tinggi, jika dilihat dari proporsinya perusahaan ini menunjukkan proporsi yang cukup kecil sebesar 3,32. Maka dapat dikatakan Plaza Indonesia Realty Tbk memiliki expected return dan risiko yang cukup proporsional.

Sedangkan perusahaan yang memiliki expected return terendah adalah Perdana Gapuraprima Tbk sebesar 0,05 dengan nilai risiko terendah pula sebesar 0,28. Artinya return akan terjadi antara $0,05-0,28=-0,23$ dan $0,05+0,28=0,33$. Namun, berdasarkan perhitungan diperoleh return bulanan Perdana Gapuraprima Tbk berada antara - 0,13 sampai dengan 1,00, sehingga hasilnya jauh berbeda. Jika dilihat dari proporsinya perusahaan ini memberikan proporsi yang paling tinggi di antara perusahaan lainnya yaitu sebesar 5,24. Maka dapat dikatakan Perdana Gapuraprima Tbk memiliki expected return dan risiko yang tidak proporsional.

Selain itu, terdapat beberapa perusahaan yang memperoleh expected return lebih besar dari ratarata yaitu Metropolitan Kentjana Tbk, Plaza Indonesia Realty Tbk, dan Roda Vivtex Tbk. Selanjutnya dapat dilihat pula perusahaan yang memiliki nilai risiko yang lebih rendah dari rataratanya yaitu Bekasi Fajar Industrial Estate Tbk, Ciputra Development Tbk, Intiland Development Tbk, Puradelta Lestari Tbk, Gowa Makassar Tourism Tbk, Perdana Gapuraprima Tbk, Jaya Real Property Tbk, Metropolitan Land Tbk, PP Properti Tbk, Pakuwon Jati Tbk, dan Summarecon Agung Tbk.

\subsection{Perbandingan Return dan Risiko Saham Subsektor Perbankan dan Subsektor Property, Real Estate}

Berdasarkan hasil statistik deskriptif dapat diketahui bahwa subsektor perbankan memiliki rata-rata return lebih besar daripada subsektor property, real estate yaitu 9,31 > 6,96. Sedangkan untuk rata-rata risiko subsektor perbankan memiliki rata-rata risiko lebih besar daripada subsektor property, real estate yaitu 26,98 $>23,05$.

Berdasarkan pengujian dengan alat Uji Mann Whitney dari kedua hipotesis memperlihatkan tidak ada perbedaan antara return serta risiko saham subsektor perbankan dengan return serta risiko saham subsektor property, real estate pada tahun 2019. Hasil ini sesuai dengan penelitian terdahulu Kasanah dan Worokinasih (2018) dengan judul "Analisis Perbandingan Return dan Risk Saham Syariah Dengan Saham Konvensional yang menunjukkan bahwa tidak ada perbedaan yang signifikan antara return dan risiko saham syariah yang berada di Jakarta Islamic Index dengan return dan risiko saham konvensional yang berada pada Indeks IDX30 periode 2014-2016. Penelitian ini juga mempunyai hasil yang sama dengan hasil penelitian Binanga, Dayaan, dan Mardhiah (2017) dengan judul "Analisis Risk dan Return Saham Syariah Tahun 2016 (Studi Perbandingan Saham Indeks Saham Syariah Indonesia Dengan Non-Indeks Saham Syariah Indonesia)" yang 
menunjukkan tidak terdapat perbedaan signifikan atas risk maupun return saham syariah dan konvensional.

Hal yang menyebabkan tidak adanya perbedaan return dan risiko saham pada subsektor perbankan dan subsektor property, real estate di antaranya karena kedua subsektor ini memiliki karakteristik yang hampir sama. Subsektor perbankan dan subsektor property, real estate merupakan dua sektor yang sangat sensitif terhadap suku bunga. Tingkat suku bunga berhubungan negatif dengan return dan risiko saham. Apabila tingkat suku bunga turun selanjutnya investor akan membeli saham (harga saham akan naik) dan lebih mempercayakan dananya untuk disimpan di pasar modal. Sebaliknya, investor akan menarik investasinya pada saham apabila tingkat suku bunga yang meningkat dan beralih pada investasi berbentuk deposito ataupun tabungan (Tandelilin, 2015).

Selain itu, di tahun 2019 kedua subsektor ini memiliki kapitalisasi pasar terbesar di antara subsektor lainnya. Kapitalisasi pasar memiliki hubungan yang positif dengan return dan risiko saham. Saham dengan market capitalization yang besar menjadi sasaran para investor untuk berinvestasi dalam jangka panjang karena memiliki potensi kinerja perusahaan yang pesat selain pembayaran dividen serta tingkat risiko yang relatif kecil (Maknun, 2008 diacu dalam Yusra, 2019). Dengan tingginya peminat, maka harga saham relatif tinggi sehingga dapat memberikan return yang tinggi pula (Lukacs, 2002 diacu dalam Yusra, 2019).

\section{Penutup}

\subsection{Kesimpulan}

Berdasarkan hasil yang diuji terhadap data return saham sebelumnya dapat diketahui bahwa H0 diterima, karena hasil nilai signifikansi data return saham lebih tinggi dari ketentuan taraf signifikansi yaitu 0,158 > 0,05 yang bermakna bahwa tidak terdapat perbedaan return yang signifikan antara antara subsektor perbankan dan subsektor property, real estate tahun 2019. Selanjutnya berdasarkan hasil pengujian terhadap risiko saham yang telah dilakukan dapat diketahui bahwa $\mathrm{H} 0$ diterima, karena hasil nilai signifikansi data risiko saham lebih tinggi dari ketentuan taraf signifikansi yaitu $0,170>0,05$ yang berarti bahwa tidak terdapat perbedaan risiko yang signifikan antara antara subsektor perbankan dan subsektor property, real estate tahun 2019. Tidak adanya perbedaan yang signifikan ini memiliki arti bahwa berinvestasi pada subsektor perbankan maupun property, real estate akan memberikan hasil return dan risiko yang sama.

\subsection{Saran}

Berdasarkan hasil pembahasan serta penelitian, maka terdapat beberapa saran yakni:

1. Bagi investor, informasi atas hasil penelitian ini dapat dijadikan rujukan dalam menentukan keputusan untuk menanamkan modal di saham.

2. Bagi penelitian berikutnya, disarankan untuk memilih periode pengamatan yang lebih lama. Sehingga dapat lebih mencerminkan kondisi masing-masing subsektor yang sebenarnya.

\section{Daftar Pustaka}

Binanga, A., Dayyan, M., \& Mardhiah, A. (2017). Analisis Risk Dan Return Saham Syariah Tahun 2016. Jurnal Investasi Islam, 2(1), 89-112.

Dividen Emiten. (n.d.). Retrieved June 5, 2020, from https://id.investing.com/equities/bnk-centralas-dividends

Fahmi, I. (2012). Pengantar Pasar Modal. Alfabeta.

Halim, A. (2018). Analisis Investasi dan Aplikasinya. Salemba Empat.

Herlambang, G. (2019). Properti Bangkit di Awal Tabun 2019. 22 Januari 2019. 
https://id.investing.com/saham-properti-bangkit-di-awal-tahun-2019

Jamil, E. R., Putra, W. E., \& Mansur, F. (2019). Perbandingan Return Saham Pada Perusahaan Perkebunan Bei Dan Bursa Malaysia. Media Riset Akuntansi, Auditing \& Informasi, 19(2), 289.

Jogiyanto. (2014). Teori dan Praktik Portofolio Dengan Excel. Salemba Empat.

Kasanah, H. R., \& Worokinasih, S. (2018). Analisis perbandingan return dan risk saham syariah dengan saham konvensional (Studi pada Jakarta Islamic Index dan IDX30 periode 20142016). Jurnal Administrasi Bisnis, 58(2), 46-55.

Kusbiyantoro, S. (2019). Perbandingan Risiko, Return Investasi , Dan Volatilitas Harga Saham Syariah Pada Sektor Pertambangan Dan Sektor Industri Barang Konsumsi Di Indeks Saham Syariah Indonesia. Universitas Islam Indonesia.

Laporan Statistik. (n.d.). Retrieved February 5, 2020, from https://www.idx.co.id/datapasar/laporan-statistik

Puspitasari, I. (2019). Pertumbuban Investor Pasar Modal. 30 Desember 2019. https://investasi.kontan.co.id/news/pertumbuhan-investor-pasar-modal-mencapai-53sepanjang-2019

Sunariyah. (2011). Pengantar Pengetahuan Pasar Modal. UPPN STIM YKPN.

Suresh, A., \& Sai, P., L. (2018). Study on Comparison of Risk-Return Analysis of Public and Private Sector Banks listed on Bank Nifty. Journal of Business Management and Economic Research, 2(1), 1 8.

Tandelilin, E. (2015). Portofolio dan Investasi. Konisius.

Tulung, J. E. (2019). Analisis Perbandingan Risiko Saham Jakarta Islamic Index Dan Indeks Lq45 Di Bursa Efek Indonesia. Jurnal EMBA: Jurnal Riset Ekonomi, Manajemen, Bisnis Dan Akuntansi, 7(3), 3239-3248.

Yusra, M. (2019). Pengaruh Frekuensi Perdagangan, Trading Volume, Nilai Kapitalisasi Pasar, Harga Saham, Dan Trading Day Terhadap Return Saham Pada Perusahaan Kosmetik Dan Keperluan Rumah Tangga Di Bursa Efek Indonesia. Jurnal Akuntansi Dan Kenangan, 7(1), 6574. 